\title{
Model Pembelajaran Mahasiswa Teknik Informatika Universitas PGRI Madiun Di Masa Pandemi Covid-19
}

Learning Model for Informatics Engineering Students at Universitas PGRI Madiun During the Covid-19 Pandemic

\author{
Sekreningsih Nita ${ }^{1}$, Davit Adi Saputra ${ }^{2}$ \\ ${ }^{12}$ Teknik Informatika; Universitas PGRI ${ }^{12}$ Madiun, Indonesia \\ e-mail:*1nita@unipma.ac.id, 2davit.adies.da@gmail.com
}

\begin{abstract}
Abstrak - Penelitian ini bertujuan untuk mengetahui pembelajaran online di Program Studi Teknik Informatika Fakultas Teknik Universitas PGRI Madiun. Metode yang digunakan pada jurnal ini dengan mengakses beberapa artikel dari world wide web yang dilakukan dengan teknik analisis data penyaringan (apply filter) oleh penulis. Beberapa artikel terkait dengan topik media pembelajaran mahasiswa khususnya mahasiswa Teknik Informatika dimasa pandemi covid-19, yang relevan dengan perangkat lunak komputer sebagai media pembelajaran. Pokok pembahasannya adalah software yang populer dimasa pandemi, khususnya yang digunakan dalam pembelajaran mahasiswa Teknik Informatika yaitu menggunakan beragam perangkat pembelajaran e-learning seperti zoom, googlemeet, google classroom, moodle serta hangout yang lebih mudah diterapkan dengan kemajuan teknologi yang ada sekarang. Daring sebagai solusi terbaik untuk memberikan pembelajaran jarak jauh sehingga memudahkan bagi mahasiwa untuk tetap mendapatkan perkuliahan tanpa tatap muka. Berdasarkan penggunaan data pada zoom sebesar 540MB/jam, GMeet 500MB/jam. Sedangkan untuk pemanggilan video, zoom 1.08GB-1.62GB dan GMeet 2.25GB. Jadi pemakaian aplikasi yang paling diminati peserta daring adalah model pembelajaran dengan platform Zoom.
\end{abstract}

Kata Kunci : Covid-19; E-learning; Google Meet; Zoom;

\begin{abstract}
This study aims to determine online learning in the Informatics Engineering Study Program, Faculty of Engineering, University PGRI Madiun. The method used in this journal is by accessing several articles from the world wide web which are carried out using filter data analysis techniques (apply filter) by the author. Several articles are related to the topic of student learning media, especially Informatics Engineering students during the Covid-19 pandemic, which are relevant to computer software as a learning media. The subject matter of the discussion is software that was popular during the pandemic, especially those used in the learning of Informatics Engineering students, namely using a variety of e-learning tools such as zoom, googlemeet, google classroom, moodle, hangout which are easier to implement with current technological advances. Online as the best solution for providing distance learning making it easier for students to still get lectures without face to face. Based on data usage at zoom of 540MB/hour, GMeet 500MB/hour. As for video calling, zoom 1.08GB-1.62GB and GMeet 2.25GB. So the use of applications that online participants are most interested in is the learning model with the Zoom platform.
\end{abstract}

Kata Kunci : Covid-19; E-learning; Google Meet; Zoom;

\section{Pendahuluan}

Media pembelajaran merupakan salah satu alat perantara yang berguna untuk memudahkan dalam proses belajar mengajar, agar memudahkan komunikasi antara dosen dan mahasiswa. Hal tersebut dinilai sangat membantu dalam proses kegiatan belajar mengajar dan memudahkan mahasiswa untuk menerima dan memahami pelajaran yang telah diberikan. 
Pemakaian media pembelajaran dalam kegiatan belajar mengajar juga bisa meningkatkan minat dan motivasi belajar mahasiswa lebih tinggi dalam proses kegiatan pembelajaran.

Namun di masa pandemi covid-19 seperti ini, kegiatan pembelajaran kuliah yang seharusnya dilakukan di kampus (secara tatap muka langsung) sekarang harus dilakukan di rumah masing-masing. Disisi lain demi tetap menjaga dunia pendidikan bisa tetap berjalan dengan baik serta mendukung Pemerintah dalam gerakan psysical distancing ditengah Pendemi Covid 19 sesuai instruksi Presiden untuk tetap dirumah, belajar dirumah, bekerja dirumah serta ibadah dirumah[1].

Pemerintah melalui Kementerian Pendidikan dan Kebudayaan juga telah menerbitkan Surat Edaran Nomor 3 Tahun 2020 tentang Pencegahan Covid-19 pada Satuan Pendidikan sebagai antisipasi terhadap penyebaran virus Corona Virus Disease 2019 (Covid-19) di berbagai sekolah maupun perguruan tinggi. Menindaklanjuti anjuran Pemerintah tersebut serta merujuk pada Surat Edaran Direktur No. 0578/Q/UNIPMA/2020 tentang kewaspadaan, kesiapsiagaan, dan antisipasi pencegahan penyebaran Covid-19 di Universitas PGRI Madiun (UNIPMA) khususnya di Prodi Teknik Informatika, maka kegiatan pembelajaran tatap muka diganti dengan bekerja dari rumah (Work From Home/WFH) oleh dosen dan belajar dari rumah (Learn Form Home/LFH) oleh mahasiswa melalui pembelajaran secara online dengan berbagai macam media[2].

Di masa pandemi seperti ini pembelajaran jarak jauhlah yang menjadi pilihan utama untuk membantu kelangsungan proses pembelajaran, maka kuliah Daring sebagai solusi yang dianggap cara terbaik untuk memutus mata rantai penyebaran virus ini. Daring memberikan pembelajaran jarak jauh dimana bahan kuliah yang diberikan melalui softfile tentu akan memudahkan bagi mahasiwa untuk tetap mendapatkan perkuliahan tanpa tatap muka. Sehingga berdasarkan uraian diatas penelitian ini bertujuan untuk menganalisa media pembelajaran yang digunakan mahasiswa di masa pandemi covid-19 khususnya Prodi Teknik Informatika Universitas PGRI Madiun.

Pembelajaran Daring sendiri bertujuan untuk memenuhi standar pendidikan dengan pemanfaatan Teknologi Informasi dengan menggunakan perangkat komputer atau gadget yang saling terhubung antara mahasiswa dan dosen atau antara dosen dengan mahasiswa sehingga melalui pemanfaatan teknologi tersebut proses belajar mengajar tetap bisa dilaksanakan dengan baik. Apalagi di Prodi Teknik Informatika tentunya lebih mengenal dengan teknologi masa kini. Pemanfaatan teknologi informasi diharapkan dapat mengatasi proses belajar mengajar bisa berjalan dengan baik meskipun tengah berada masa pendemi Virus Covid 19. Pilihan ini harus diambil untuk melakukan tindakan pencegahan penularan wabah virus yang kini telah menjadi pandemi global serta memutus penyebaran virus covid 19 . Solusi terbaik dengan kemampuan mahasiswa khususnya Prodi Teknik Informatika dalam menggunakan beragam perangkat pembelajaran e-learning seperti zoom, googlemeet, google classroom, modle, hangout secara daring lebih mudah diterapkan dengan kemajuan teknologi yang ada sekarang.

\section{LANDASAN TEORI}

\section{A. Media Pembelajaran}

Media pembelajaran adalah sesuatu yang dapat digunakan untuk menyalurkan pesan (bahan pembelajaran) sehingga dapat menambah, minat, pikiran, dan motivasi belajar pada siswa dalam proses pembelajaran untuk mencapai pembelajaran yang baik[3][4].

Cecep Kustandi dan Bambang Sutjipto [5]berpendapat bahwa media pembelajaran adalah alat yang dapat membantu proses belajar mengajar dan berfungsi untuk memperjelas makna pesan yang disampaikan, sehingga dapat mencapai tujuan pembelajaran dengan baik dan sempurna.

Dari beberapa pendapat mengenai pengertian dari media pembelajaran diatas dapat disimpulkan bahwa Media Pembelajarn adalah suatu alat bantu yang digunakan untuk membantu proses belajar mengajar dan memperjelas makna pesan yang disampaikan sehingga dapat menanbah minat dan motivasi belajar utuk mencapai tujuan pembelajan yang baik.

Penggunaan media pembelajaran bukan merupakan fungsi tambahan pada saat proses pembelajaran, tetapi memiliki fungsi tersendiri sebagai sarana untuk mewujudkan pembelajaran yang lebih menarik dan efektif sehingga siswa lebih mudah memahaminya[4].

Fungsi penggunaan media pembelajaran yaitu[2]:

1. Membantu memudahkan belajar bagi siswa dan membantu memudahkan mengajar bagi guru. 
2. Lebih menarik perhatian dan minat murid dalam belajar.

3. Kegiatan pembelajaran dapat berjalan lebih menyenangkan dan tidak membosankan.

\section{B. Covid-19.}

Merupakan infeksi virus baru, virus ini bermula di Wuhan, China 31 Desember 2019. Virus yang merupakan virus RNA Strain tunggal positif ini menginfeksi saluran pernafasan. Dilihat dari beberapa gejalanya seperti demam, batuk, dan sulit bernafas. Seseorang yang mengalami demam ( >380C ), batuk atau pilek atau nyeri tenggorokan. Pengambilan swab tengorokan dan saluran nafas menjadi dasar penegakan diagnosis corona virus disease[6].

\section{E-Learning.}

Kemajuan teknologi informasi dan komunikasi saat ini memberikan banyak kemudahan dan kemungkinan dalam membuat suatu perancangan dan pengembangan sistem pendidikan, khususnya pada saat pandemi seperti ini konsep dan model pembelajaran semuanya harus secara online[7].

E-learning adalah sebuah alat teknologi informasi dan komunikasi yang membuat siswa untuk belajar kapanpun dan dimanapun[8].

Menurut Michael [9], adalah Pembelajaran yang disusun ialah dengan tujuan menggunakan suatu sistem elektronik atau juga komputer sehingga mampu untuk mendukung suatu proses pembelajaran

Selain itu, [10], E-learning adalah suatu sistem pembelajaran yang digunakan ialah sebagai sarana ialah sebagai proses belajar mengajar yang dilaksanakan tanpa harus bertatap muka dengan secara langsung .

Dari beberapa pendapat mengenai pengertian dari e-learning dapat disimpulkan bahwa Elearning adalah alat teknologi informasi dan komunikasi yang digunakan untuk mendukung suatu proses pembelajaran tanpa harus bertatap muka.

Manfaat E-learning dengan menurut Pranoto, dkk [7] sebagai berikut:

1. Meningkatkan suatu partisipasi aktif dari mahasiswa.

2. Meningkatkan suatu kemampuan belajar mandiri mahasiswa.

3. Meningkatkan kemampuan dalam menampilkan informasi dengan perangkat teknologi informasi.

Namun menurut [8] ada juga kendala dari kuliah daring yaitu :
1. Jaringan yang tidak stabil.

2. Mahasiswa yang sulit memahami dengan cara ini.

3. Listrik yang bisa padam ketika mengakses pembelajaran.

4. Kesalah pahaman antara dosen dengan mahasiswa.

\section{METODE}

Metode yang digunakan pada jurnal ini adalah studi literatur yaitu cara yang dipakai untuk menghimpun data-data atau sumber-sumber yang berhubungan dengan topik yang diangkat dalam suatu penelitian. Studi literatur bisa didapat dari berbagai sumber, jurnal, buku dokumentasi, internet dan pustaka. Teknik analisis data yang dilakukan penulis adalah dengan melakukan penyaringan (apply filter), berdasarkan judulnya yang berkaitan dengan software pembelajaran, dan topiknya.

Kriteria pada judul setidaknya terdapat kata software, aplikasi, pembelajaran, kampus, dan pandemi. Dengan demikian penulis dapat lebih menyaring artikel dan mencocokkan pokok bahasan yang menjadi inti permasalahannya untuk dijadikan bahan bacaan dan rujukan pada ulasan jurnal ini.

\section{HASIL DAN PEMBAHASAN}

Dimasa pandemi Covid-19 saat ini, banyak orang menyadari akan pentingnya penggunaan perangkat lunak komputer (software) dalam proses pembelajaran daring. Untuk pencegahan penyebaran infeksi virus corona (Covid-19) di Universitas PGRI Madiun, maka pelaksanaan kegiatan akademik (pembelajaran tatap muka dengan mahasiswa) dalam masa pandemi / penyebaran Covid 19 ditiadakan.

Kegiatan akademik selama pandemi untuk pembelajaran tatap muka diganti dengan Learn From Home (LFH) yaitu belajar dari rumah oleh mahasiswa dan bagi dosen melakukan kegiatan bekerja dari rumah Work From Home (WFH). Gambar 1 merupakan salah satu contoh pembelajaran daring yang dilakukan antara dosen dan mahasiswa yaitu dengan media google meet. 


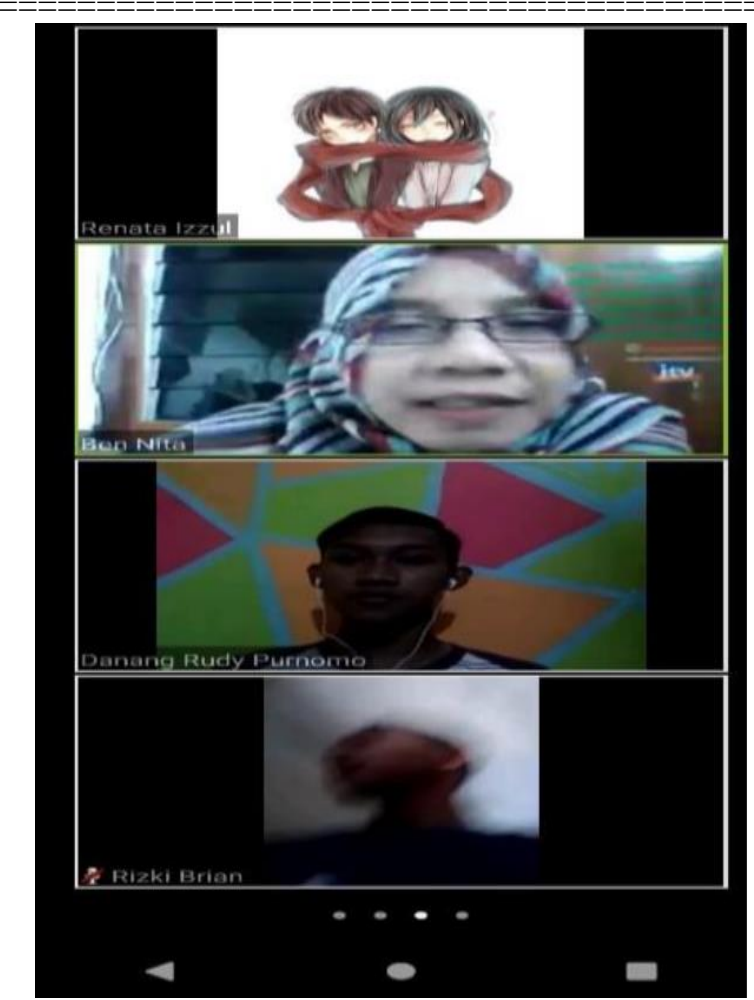

Gambar 1. Proses Pembelajaran melalui aplikasi Google Meet.

Kuliah daring sebagai salah satu solusi pembelajaran dimasa covid-19 ini, dianggap cara yang terbaik untuk memutus mata rantai penyebaran virus ini seperti yang ada pada Gambar 1. Pilihan ini harus diambil untuk melakukan tindakan pencegahan yang efektif atas wabah yang kini telah menjadi pandemi global. Kebijakan yang diambil diantaranya ialah mentiadakan kegiatan perkuliahan di lingkungan kampus serta melakukan karantina mandiri mahasiswa, dosen, dan tenaga kependidikan, karyawan lainnya dan termasuk tidak melakukan pertemuan tetapi melakukan perkuliahan dan bimbingan secara daring. Karena pada hakikatnya proses belajar adalah proses komunikasi (proses penyampaian pesan) yang harus diwujudkan melaui kegiatan penyampaian dan tukar menukar pesan atau informasi oleh setiap dosen dan mahasiswa. Pesan atau informasi dapat berupa pengetahuan, keahlian, skill, ide, pengalaman dengan menggunakan media aplikasi seperti google classroom, zoom, google meet, dan sebagainya.

Beberapa artikel yang menjadi bahan bacaan pada ulasan jurnal ini, yang menunjukkan begitu banyaknya penggunaan perangkat lunak (software) dalam proses pembelajaran dimasa pandemi covid-19. Terkadang kita menyebut software dengan sebutan 'aplikasi' atau 'program'. Dengan adanya software, dapat difungsikan dengan baik untuk menunjang aktifitas kita, terlebih di masa pandemi. Contohnya ketika kita ingin menulis laporan, membuat desain gambar. Apalagi mahasiswa, yang harus tetap melakukan proses pembelajaran daring, dengan banyak membutuhkan berbagai software pendukung.

Berikut beberapa software atau aplikasi yang digunakan selama masa pandemi covid 19 saat ini :

Tabel 1. Jenis Aplikasi

\begin{tabular}{ll}
\hline Aplikasi & Keterangan \\
\hline & Aplikasi buatan miliarder, Eric
\end{tabular}

1. Zoom Yuan, yang dirilis pada Januari 2013. Selain aplikasi, Zoom juga dapat diakses melalui website. Ketika mendaftarkan diri, kamu berada di jenis akun Basic yang memiliki beberapa keuntungan, seperti : Dapat melakukan meeting hingga 100 partisipan, dan dapat mengulang lagi jika durasi sudah habis, kualitas suara dan gambar HD, screen-sharing, akses ke virtual background, menjadwalkan hingga merekam keseluruhan meeting[11].

2.Google Suatu learning management

Classroom system yang dapat digunakan untuk menyediakan bahan ajar, tes yang terintegrasi penilaian. Berbeda dengan media pembelajaran yang lain keunggulan media google class room adalah masalah efektifitas dan efisiensi dalam pembelajaran[12][13].

3.Google Google Meet adalah salah satu
Meet aplikasi atau software yang dapat dimanfaatkan untuk tetap produktif dalam bekerja meski dilakukan dari rumah.Google Meet memungkinkan pengguna untuk melakukan panggilan video dengan 30 pengguna lainnya per pertemuan. Dengan kata lain, Google Meet bisa menjadi media alternatif untuk pembelajaran secara online[14]

\begin{tabular}{|c|c|}
\hline 4. Moodle & $\begin{array}{l}\text { Agar proses belajar mengajar } \\
\text { lebih interaktif, } \\
\text { menyediakan berbagai aktifitas } \\
\text { yaitu : Assignments, Choices, }\end{array}$ \\
\hline & dan Journal. Moodle juga \\
\hline
\end{tabular}




\begin{tabular}{|c|c|}
\hline Aplikasi & Keterangan \\
\hline & $\begin{array}{l}\text { menyediakan lima jenis fitur } \\
\text { untuk aktivitas interaksi antara } \\
\text { siswa dengan siswa maupun } \\
\text { siswa dengan guru. Fitur tersebut } \\
\text { adalah : chat, forum, glossary, } \\
\text { wiki, dan workshop[15]. }\end{array}$ \\
\hline 5. Hangouts & $\begin{array}{l}\text { Sebuah platform komunikasi } \\
\text { yang dikembangkan oleh Google } \\
\text { yang mencakup instant } \\
\text { messaging, video chat. Selain itu } \\
\text { hangouts bisa chatting sambil } \\
\text { video call bahkan dengan } 10 \\
\text { orang sekaligus[16]. }\end{array}$ \\
\hline
\end{tabular}

Masing-masing layanan aplikasi model pembelajaran seperti pada tabel di atas mempunyai kelebihan dan kekurangan dari fitur yang ditawarkan. Namun ada satu pertimbangan utama dalam memilih platform pembelajaran secara daring yaitu kuota data internet yang dikonsumsi selama digunakan.

Dari ke-5 aplikasi yang dijadikan pilihan, ada 2 aplikasi yang paling diminati yaitu Zoom dan Google Meet.

Berdasarkan pertimbangan utama memilih platform dengan kriteria kualitas video, jumlah orang yang melakukan streaming video, jumlah orang yang dapat dilihat, maka dapat diambil kesimpulan sebagai berikut :

a. Untuk panggilan video satu lawan satu, Zoom menggunakan sekitar 540MB per jam untuk standar kualitas tinggi. Konsumsi meningkat menjadi 1,08GB per jam untuk kualitas 720p dan sekitar 1,62GB per jam untuk streaming 1080p

b. Penggunaan data meningkat secara signifikan saat pemanggilan video grup, zoom memakan 810MB per jam, 1,35GB per jam, dan 2,4GB per jam, masing-masing untuk panggilan konferensi grup standar, 720p, dan 1080p.

c. Banyaknya data yang dkonsumsi selama 1 jam konferensi video yang dilakukan oleh Google Meet : bandwidth rata-rata Google Meet per peserta adalah $3.2 \mathrm{Mbps}$ inbound dan $1.8 \mathrm{Mbps}$ outbound. Ini berarti konsumsi data sekitar 2,25GB per jam dalam kualitas tinggi.

d. Secara default, Google Meet otomatis menyesuaikan bandwidth masuk dan keluar berdasarkan koneksi yang dipakai, tingkat konsumsi data sangat bervariasi. menunjukkan penggunaan sangat sedikit data pada versi seluler yakni sekitar 500MB per jam.

Tabel 2. Data Pemakaian Aplikasi Daring

\begin{tabular}{clcc}
\hline No & Klasifikasi/kriteri & Zoom & GMeet \\
\hline 1 & Pemanggilan & $1.08 \mathrm{~GB}$ & $2.25 \mathrm{~GB}$ \\
& video/jam/peserta & $(720 \mathrm{p})$ & $(3.2 \mathrm{Mbps}$, \\
& & $1.62 \mathrm{~GB}$ & $1.8 \mathrm{Mbps})$ \\
& & $(1080 \mathrm{p})$ & \\
\hline 2 & Streaming video & $1.35 \mathrm{~GB}$ & default \\
& grup/jam & $(720 \mathrm{p})$ & \\
& & $2.4 \mathrm{~GB}$ & \\
& & $(1080 \mathrm{p})$ & \\
\hline 3 & Pengunaan data/jam & $540 \mathrm{MB}$, & $500 \mathrm{MB}$ \\
& & $810 \mathrm{MB}$ & \\
\hline
\end{tabular}

Dengan menggunakan aplikasi zoom dan google meet sebagai media pembelajaran online maka aktivitas pembelajaran yang dilakukan secara daring dapat diimplementasikan dengan lancar dikarenakan fasilitias yang ada didalamnya antara lain pemanggilan video, steaming videa dan penggunaan data lebih fleksibel serta kapasitas peserta lebih memadai, (Permana, P,N,2020)

\section{KESIMPULAN}

Dari perbandingan di atas, baik Google Meet dan Zoom sama-sama berupaya mengoptimalkan jumlah konsumsi transfer data yang dihitung dalam satuan waktu bit per second. Keduanya juga menyesuaikan berapa banyak video yang digunakan selama panggilan berlangsung. Zoom memiliki berbagai fitur yang apabila semuanya dioptimalkan, semakin sedikit data yang terbuang. Untuk penggunaan data pada zoom sebesar 540MB/jam, GMeet 500MB/jam. Sedangkan pada pemanggilan video untuk zoom 1.08GB-1.62GB dan GMeet 2.25GB. Jadi pemakaian aplikasi yang paling diminati peserta daring adalah model pembelajaran dengan platform Zoom.

\section{DAFTAR PUSTAKA}

[1] Yuliana, "Yuliana (2020). Corona Virus Diseases (Covid-19); Sebuah Tinjauan Literatur.,"Wellness Heal. Mag., vol. 2, no. February, pp. 124-137, 2020, doi: 10.2307/j.ctvzxxb18.12.

[2] U. Basyiruddin and Asnawir, Media Pembelajaran. Jakarta Selatan: Ciputat Pers, 2002.

[3] A. Nurul Ikhwan, "Penggunaan software dalam mpembelajaran kampus di sasa pandemi covid-19 : studi literatur," 2020.

[4] H. Prasetyo and Nurhayati, "Pengembangan Media Pembelajaran Interaktif Berbasis Cai ( 
Computer - Assisted Instruction ) Pada Mata Pelajaran Teknik Elektronika Dasar Kelas X Di Smkn 1 Nganjuk," J. Pendidik. Tek. elektro, vol. 4, no. 1, pp. 103-108, 2015.

[5] C. Kuatandi, B. Sutjipto, and R. Sikumbang, Media Pembelajaran Manual dan Digital. Bogor: Ghalia Indonesia, 2013.

[6] R. N. Putri, "Indonesia dalam Menghadapi Pandemi Covid-19," J. Ilm. Univ. Batanghari Jambi, vol. 20, no. 2, p. 705, 2020, doi: 10.33087/jiubj.v20i2.1010.

[7] A. Pranoto, Sains dan teknologi. Jakarta: PT Gramedia Utama, 2009.

[8] S. Dahiya, S. Jaggi, K. K. Chaturvedi, A. Bhardwaj, R. C. Goyal, and C. Varghese, "An eLearning System for Agricultural Education," Indian Res. J. Ext. Edu, vol. 12, no. 3, pp. 132-135, 2012.

[9] M. Allen, Michael Allen's Guide to Elearning. Canada: John Wiley \& Sons, 2013.

[10] H. Ardiansyah, "PENGARUH PENERAPAN METODE PEMBELAJARAN BRAINSTORMING DAN PROBLEM BASED INSTRUCTION TERHADAP AKTIVITAS BELAJAR DAN PEMAHAMAN KONSEP PESERTA DIDIK: Studi Eksperimen Pada Mata Pelajaran Ekonomi Pada Siswa Kelas X SMA Kartika Siliwangi 2 Bandung Tahun Ajaran ," Universitas Pendidikan Indonesia, 2013.

[11] D. Haqien and A. A. Rahman, "Pemanfaatan Zoom Meeting untuk Proses Pembelajaran pada Masa Pandemi Covid-19," SAP (Susunan Artik. Pendidikan), vol. 5, no. 1, 2020, doi: 10.30998/sap.v5i1.6511.

[12] D. Sutrisna, "Meningkatkan Kemampuan Literasi Mahasiswa Menggunakan Google Classroom," FON J. Pendidik. Bhs. dan Sastra Indones., vol. 13, no. 2, pp. 69-78, 2018, doi: 10.25134/fjpbsi.v13i2.1544.

[13] N. Asnawi, "Pengukuran Usability Aplikasi Google Classroom Sebagai E-learning Menggunakan USE Questionnaire (Studi Kasus: Prodi Sistem Informasi UNIPMA)," Res. Comput. Inf. Syst. Technol. Manag., vol. 1, no. 1, pp. 17-21, 2018, [Online]. Available: http://e-

journal.unipma.ac.id/index.php/RESEARCH/a rticle/view/2451/pdf.

[14] R. S. Al-Maroof, S. A. Salloum, A. E. Hassanien, and K. Shaalan, "Fear from COVID-19 and technology adoption: the impact of Google Meet during Coronavirus pandemic," Interact. Learn. Environ., vol. 0, no. $0, \quad$ pp. $1-16, \quad 2020$, doi: 10.1080/10494820.2020.1830121.

[15] W. Rice and S. S. Nash, Moodle 1.9 Teaching Techniques. Birmingham: PACKT, 2010.

[16] J. He and X. Huang, "Collaborative Online Teamwork: Exploring Students' Satisfaction and Attitudes with Google Hangouts as a Supplementary Communication Tool," J. Res. Technol. Educ., vol. 49, no. 3-4, pp. 149-160, 2017, doi: 10.1080/15391523.2017.1327334. 